\title{
Section Three: LC Genre/Form Terms For Religious Materials Project
}

Janis Young at LC reports that the religion genre/form terms document submitted in August 2012 will be reviewed this year. Staff changes at LC have made it impossible to adhere to the planned schedule.

Submitted by

Erica Treesh, Database Manager for Religion Complete $\left(A T L A R D B^{\circledR}\right)$

American Theological Library Association

\section{NEWS}

\section{PROFESSIONAL DEVELOPMENT OPPORTUNITIES}

\section{Weeding the Academic Library with Confidence}

Online Course via Library Juice Academy

Provides guidance on how to identify what to keep and what to withdraw, how to address faculty concerns, and what to do with the deaccessioned materials.

June 1-26, 2015

$\$ 175$

http://libraryjuiceacademy.com/042-weeding.php

Planning for the Evolving Role of Metadata Services

ALCTS Virtual Preconference

Three sessions, which can be attended individually, cover the emerging responsibilities of metadata specialists, assessment of metadata workflows, and standardizing and sharing vocabularies.

June 2-4, 2015

$\$ 43-\$ 249$

http://www.ala.org/alcts/confevents/upcoming/webinar/060215

Copy Cataloging of Digital Resources: Virtual/

Webinar provided by MCLS

Internet Resources \& Video Games Using RDA

This three-part hands-on workshop teaches participants how to catalog virtual and physical digital resources using the RDA Toolkit, the Library of Congress Cataloging Policy Statements, and Library of Congress Subject Headings Manual. Also included is discussion about assigning appropriate subject headings for digital resources.

June 16-18, 2015

$\$ 99-\$ 199$

http://tinyurl.com/qxsggtr

\section{Linked Data and BIBFRAME Practical}

Webinar provided by Zepheira

\section{Practitioner Training}

A self-paced course that helps participants answer the question: Is my library ready for Linked Data, BIBFRAME, or the Web of Data? The course is designed to help all library staff understand the fundamentals of connecting data to the web in meaningful ways so that a plan can be established for each library. A variety of learning methodologies are used, including videos, discussion forums, exercises, and virtual meetings as well as using your own library data within Zepheria's training tools.

Beginning June 19, 2015 for 5 to 6 weeks

$\$ 1,500$

http://zepheira.com/solutions/library/training/

Copy Cataloging of Monographs using RDA

Webinar provided by MCLS

Using RDA Toolkit, this hands-on workshop will provide a better understanding of how to transition from AACR2 to RDA. Included with the workshop is a booklet that contains an RDA workflow.

June 28-30, 2015

\$99-\$199

http://tinyurl.com/m74658q 
This course covers basic principles of preventive care including environmental conditions, storage, and handling to extend the life of the materials. Developing a disaster response plan will also be addressed.

September 7-October 2, 2015

http://libraryjuiceacademy.com/107-caring-collections.php

Submitted by

Leslie Engelson, Metadata Librarian

Murray State University

\section{SELECTED ARTICLES FROM CURRENT LIBRARY JOURNALS}

Colson, Jeannie, and Kelly Allen. "Our Trek to DISCOVERY." Online Searcher 39, no. 2 (March 2015): 45-49. http:// www.infotoday.com/OnlineSearcher/Articles/Features/Our-Trek-to-Discovery-A-Tale-of-Implementation-102366.shtml

Engelson, Leslie A. Subdivisions for Biblical Studies, Theology, and Ministry: Making Search Terms Do the Work. Chicago, IL: ATLA, 2014. https://books.atla.com/index.php/atla/catalog/book/7

Enis, Matt. "Ending the Invisible Library." Library Journal 140, no. 3 (February 15, 2015): 36. http://lj.libraryjournal. com/2015/02/technology/ending-the-invisible-library-linked-data/

Goedeken, Edward A., and Karen Lawson. "The Past, Present, and Future of Demand-Driven Acquisitions in Academic Libraries." College E Research Libraries 76, no. 2 (March 2015): 205-221. http://crl.acrl.org/content/76/2/205.full. pdf+html

Gonzales, Brighid M. "Linking Libraries to the Web: Linked Data and the Future of the Bibliographic Record." Information Technology E Libraries 33, no. 4 (December 2014): 10-22. http://ejournals.bc.edu/ojs/index.php/ital/ article/view/5631

Gross, Tina, Arlene G. Taylor, and Daniel N. Joudrey. "Still a Lot to Lose: The Role of Controlled Vocabulary in Keyword Searching." Cataloging E Classification Quarterly 53, no. 1 (January 2015): 1-39.

Lisius, Peter H. "AACR2 to RDA: Is Knowledge of Both Needed during the Transition Period?." Cataloging E Classification Quarterly 53, no. 1 (January 2015): 40-70.

Moulaison, Heather Lea. "The expansion of the personal name authority record under Resource Description and Access: Current status and quality considerations." IFLA Journal 41, no. 1 (March 2015): 13-24.

Submitted by

Anna Appleman, Copy Cataloger

John Bulow Campbell Library, Columbia Theological Seminary 